\title{
Low Prevalence of Autoantibodies to the Insulin-like Growth Factor I Receptor in Children with Short Stature
}

\author{
KATHLEEN THOMPSON, DAVID P. DEMPSHER, DENNIS M. BIER, AND \\ SHERIDA E. TOLLEFSEN
}

The Edward Mallinckrodt Department of Pediatrics, Washington University School of Medicine, and the Division of Endocrinology/Metabolism. Children's Hospital, St. Louis, Missouri 63110

\begin{abstract}
Inhibition of IGF-I action by circulating IGF-I receptor autoantibodies is a potential mechanism of IGF-I resistance in growing children. To define the prevalence of IGF-I receptor antibodies in short-statured children, we have examined serum and plasma samples from a well-characterized group of 34 short, prepubertal, growth hormone-sufficient children and three growth hormonedeficient children. IGF-I receptor purified from human placental membranes was radioiodinated by the solid phase radioiodination method. Serum from a patient with severe insulin resistance immunoprecipitated $28.9-44.7 \%$ of the ${ }_{125}$ I-labeled IGF-I receptor. The ranges (mean $\pm 3 \mathrm{SD}$ ) of ${ }^{125}$ I-labeled IGF-I receptor immunoprecipitated by 1:10 diluted and by undiluted nonimmune human serum were $1.99 \pm 0.63 \%$ and $4.42 \pm 1.32 \%$, respectively. Immunoprecipitation of the ${ }^{125}$ I-labeled IGF-I receptor by eight samples from six children was $>3$ SD above the mean when assayed at a 1:10 dilution. Nevertheless, when assayed undiluted, only one of these samples immunoprecipitated slightly more ${ }^{125}$ I-labeled IGF-I receptor than nonimmune serum. We conclude from these data that immunoprecipitating autoantibodies to the IGF-I receptor are not commonly present in short-statured children. (Pediatr Res 32: 455-459, 1992)
\end{abstract}

IGF-I is a major mammalian postnatal growth factor that is regulated at least in part by pituitary growth hormone (1). In responsive cells, IGF-I interacts with the IGF-I receptor, a heterotetrameric glycoprotein composed of two disulfide-linked $\alpha \beta$ dimers. The IGF-I receptor is a member of the tyrosine kinase family of growth factor receptors (2) and is structurally homologous to the insulin receptor (3). IGF-I binding to the IGF-I receptor causes the transmembrane activation of the intrinsic tyrosine kinase activity of the IGF-I receptor, which, by mechanisms that are not yet well understood, results in both rapid insulin-like effects on intermediary metabolism and more longterm effects on growth (4).

Autoimmunity to receptors within the endocrine system has been well documented (5). In patients with severe insulin resistance type $B$, autoantibodies to the insulin receptor have been shown to inhibit insulin action (6). Because of the close homology between the insulin receptor and the IGF-I receptor, Tappy $e t$ al. (7) examined sera from patients with disorders reported to

Received January 10, 1992; accepted May 7, 1992.

Correspondence: Sherida E. Tollefsen, M.D., Washington University School of Medicine, Department of Pediatrics, 400 South Kingshighway, St. Louis, MO 63110.

Supported in part by United States Public Health Service Grants HD20805 and DK42658 and Research Career Development Award DK01978 (to S.E.T.). have an increased prevalence of insulin receptor antibodies to determine if these sera contained autoantibodies to the IGF-I receptor. Eleven of the 141 patient sera tested (7.8\%) immunoprecipitated labeled IGF-I receptor. Sera from seven patients contained IgG autoantibodies that did not inhibit IGF-I binding, whereas sera from four patients contained antibodies that bound to the IGF-I receptor at or near the IGF-I binding site and inhibited IGF-I binding. Two of these patients had elevated plasma IGF-I levels, suggesting that they were IGF-I resistant.

Inhibition of IGF-I action by IGF-I receptor autoantibodies would be anticipated to have a significant effect on growth in children. We previously reported (8) the whole body nitrogen kinetics and their relationship to growth in a well-characterized group of 34 short, prepubertal, growth hormone-sufficient children and three growth hormone-deficient children. No mutations were detected in the growth hormone or IGF-I genes of any patients in this study, and the fibroblasts from the 34 nongrowth hormone-deficient children responded normally when challenged with recombinant human IGF-I. In this report, we examine serum and plasma from these patients to define the prevalence of immunoprecipitating IGF-I receptor antibodies in short-statured children.

\section{MATERIALS AND METHODS}

Materials. Iodine-125 was purchased from Du Pont/New England Nuclear Research Products (Boston, MA) $(17.4 \mathrm{Ci} / \mathrm{mg} \mathrm{I})$ or from Amersham Corp. (Arlington Heights, IL) (14.5 Ci/mg I). Enzymobead Radioiodination Reagent and Bio-Gel P-2 (200400 mesh) were produced by Bio-Rad Laboratories (Richmond, CA). Sephacryl S-200 Superfine was obtained from Pharmacia LKB Biotechnology (Piscataway, NJ). Triton X-100, BSA, leupeptin, phenylmethylsulfonyl fluoride, and aprotinin were purchased from Sigma Chemical Co. (St. Louis, MO). Serum from a patient with severe insulin resistance who had high titers of antibodies to the insulin receptor was a gift of Dr. James $R$. Gavin III (University of Oklahoma Health Sciences Center, Oklahoma City, OK). The MAb to the IGF-I receptor, $\alpha$ IR-3 $(0.5 \mathrm{mg} / \mathrm{mL})$, was generously provided by Dr. Steven Jacobs (The Wellcome Research Laboratories, Research Triangle Park, NC). Pansorbin (fixed protein A-bearing Staphylococcus aureus cells, $10 \% \mathrm{wt} / \mathrm{vol}$, binding capacity of $2.0-2.4 \mathrm{mg}$ human IgG/ $\mathrm{mL}$ ) was produced by Behring Diagnostics (San Diego, CA). These cells have been reported to bind $\operatorname{IgG} 1, \operatorname{IgG} 2, \operatorname{IgG} 4, \operatorname{IgA} 2$, and some IgM in human serum (9).

Subjects. Thirty-seven prepubertal children between the ages of 4.2 and $13.8 \mathrm{y}$ and $>2$ SD below the mean height for age were recruited from the Washington University Pediatric Endocrinology Clinic. Their clinical characteristics have been previously summarized (8). Thirty patients had normal levels of serum IGF-I, and seven patients had serum IGF-I levels $>2$ SD below 
the mean for their age or pubertal status and gender. Informed consent had been obtained from all families according to procedures approved by the Washington University Human Studies Committee.

Purification of IGF-I receptor from human placental membranes. The high-affinity IGF-I receptor was purified from normal full-term human placentas using wheat germ agglutininSepharose chromatography, insulin affinity chromatography, and IGF-I affinity chromatography, as previously described (10).

Radioiodination of purified IGF-I receptor. Purified IGF-I receptor was concentrated four times in a Centricon 30 microconcentrator (Amicon Corp., Danvers, MA) and then dialyzed against PBS at $4^{\circ} \mathrm{C}$ on an MF-Millipore membrane filter $(0.05$ $\mu \mathrm{m})$. Radioiodination of the receptor $(0.5-2.1 \mathrm{pmol})$ was performed with Enzymobead Radioiodination Reagent, according to the manufacturer's instructions. As shown in Figure 1, the reaction mixture, containing the labeled IGF-I receptor, and a $50-\mu \mathrm{L}$ wash of the reaction vial were applied to a Bio-Gel P-2 column $(1 \times 24 \mathrm{~cm})$ equilibrated in PBS with $0.1 \%$ Triton X100 to separate bound from free ${ }^{125} \mathrm{I}$. Fractions $(0.5 \mathrm{~mL})$ were collected at a flow rate of $9 \mathrm{~mL} / \mathrm{h}$, and radioactivity was monitored by counting $1-\mu \mathrm{L}$ aliquots in a Micromedic Automatic Gamma Counter (Micromedic Systems, Inc., Horsham, PA). Void volume fractions from the Bio-Gel P-2 column were pooled and applied to a Sephacryl S-200 column $(1.5 \times 46 \mathrm{~cm})$ equilibrated in PBS with $0.1 \%$ Triton X-100. Fractions $(1.0 \mathrm{~mL})$ were collected at a flow rate of $18 \mathrm{~mL} / \mathrm{h}$, and radioactivity was monitored by counting $5-\mu \mathrm{L}$ aliquots. Peak fractions containing the ${ }^{125} \mathrm{I}$-labeled IGF-I receptor were pooled and stored at $-20^{\circ} \mathrm{C}$ until use. The ${ }^{125}$ I-labeled IGF-I receptor had a sp act of 1.3-8.5 $\mu \mathrm{Ci} / \mathrm{pmol}$ and was used within $2 \mathrm{wk}$ of its preparation.

SDS-PAGE and autoradiography. SDS-PAGE was performed according to the method of Laemmli (11) with $7.5 \%$ or $3-10 \%$ gradient acrylamide resolving gels. Electrophoresis sample buffer was added to samples at a final concentration of $1 \%$ SDS or $2 \%$ SDS with $5 \% \beta$-mercaptoethanol, and samples were heated at $100^{\circ} \mathrm{C}$ for $2 \mathrm{~min}$ or $5 \mathrm{~min}$, respectively. Molecular weight standards (Bio-Rad) included myosin (200 000), $\beta$-galactosidase (116 250), phosphorylase b (97 400), BSA (66 200), and ovalbumin (42 700). Prestained molecular weight standards (Bio-Rad) included all of the above except phosphorylase $b$. Gels were either fixed in $50 \%$ methanol/10\% acetic acid for $1 \mathrm{~h}$ or fixed, stained, and destained as previously described (12). The gels were then dried and exposed to Kodak XAR-5 x-ray film in the presence of a Du Pont Cronex Lightning-Plus intensifying screen at $-70^{\circ} \mathrm{C}$. Autoradiographs were scanned with an LKB Ultroscan $\mathrm{XL}$ laser densitometer.

Immunoprecipitation of IGF-I receptor. Before use, Pansorbin was washed twice with PBS with $1 \mathrm{mg} / \mathrm{mL}$ BSA (washing buffer). ${ }^{125}$ I-labeled IGF-I receptor was then precleared by incubation for $30 \mathrm{~min}$ at $4^{\circ} \mathrm{C}$ with an equal volume of $10 \%$ Pansorbin in washing buffer with $0.1 \%$ Triton $X-100$ and protease inhibitors $(1 \mu \mathrm{g} / \mathrm{mL}$ leupeptin, $0.2 \mathrm{mM}$ phenylmethlysulfonyl fluoride, and $20 \mu \mathrm{g} /$ $\mathrm{mL}$ aprotinin) and centrifugation at $15500 \times \mathrm{g}$. The supernatant was removed and used directly in the immunoprecipitation assay. In eight experiments, $1.8-4.8 \%$ of the ${ }^{125} \mathrm{I}$ label was removed from the ${ }^{125}$ I-labeled IGF-I receptor by preclearance with $10 \%$ Pansorbin.

Precleared receptor $(\sim 25000 \mathrm{cpm} / 45 \mu \mathrm{L})$ was incubated overnight at $4^{\circ} \mathrm{C}$ with $5 \mu \mathrm{L}$ diluted or undiluted patient serum or plasma, nonimmune human serum, or serum from a patient with severe insulin resistance. Sample dilutions used are described in the legends to Figures 2 and 3 and were prepared in PBS. To precipitate immune complexes, samples were incubated with $75 \mu \mathrm{L}$ of a $20-40 \%$ suspension of Pansorbin in washing buffer for $30 \mathrm{~min}$ at $4^{\circ} \mathrm{C}$. Because different Pansorbin preparations were used in our experiments, each lot was tested to determine the percentage of Pansorbin required to maximally precipitate receptor-antibody complexes using undiluted immune serum. After centrifugation at $15500 \times g$, the supernatants
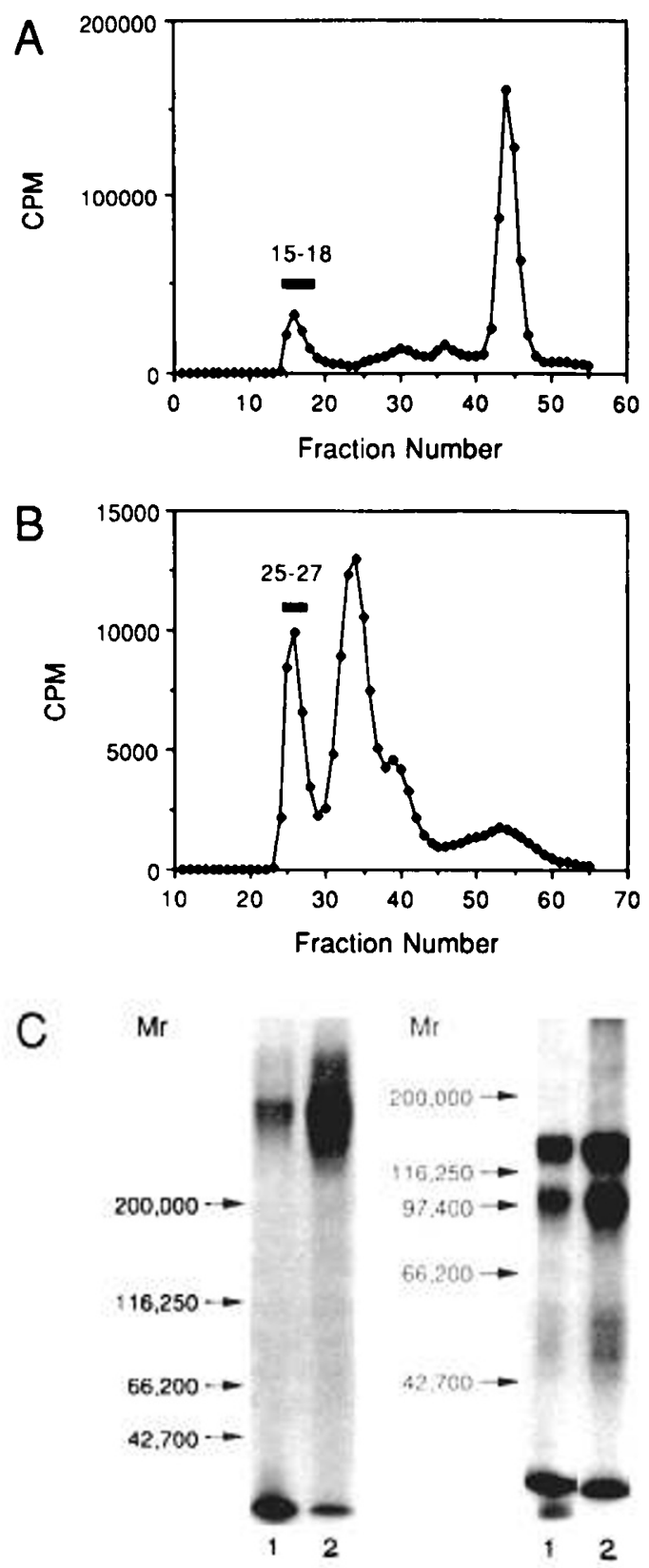

Fig. 1. Column chromatography profiles and SDS-PAGE analysis of the ${ }^{125}$ I-labeled IGF-I receptor. Purified IGF-I receptor was concentrated, dialyzed, and radioiodinated as described in Materials and Methods. $A$, elution profile from the Bio-Gel P-2 gel filtration column. Void volume fractions $(15-18)$ from the Bio-Gel P-2 column were pooled and applied to a Sephacryl S-200 column. $B$, elution profile from the Sephacryl S200 gel filtration column. Fractions $25-27$ containing the ${ }^{125}$ I-labeled IGF-I receptor were pooled and used in the immunoprecipitation studies. $C$, autoradiographs of the ${ }^{125}$ l-labeled IGF-I receptor analyzed by SDSPAGE. Left lanes, samples analyzed under nonreducing conditions using a 3-10\% gradient acrylamide resolving gel. The migration of prestained molecular weight standards is indicated. Right lanes, samples analyzed under reducing conditions using a $7.5 \%$ acrylamide resolving gel. The migration of molecular weight standards is indicated. Lanes $I, 5-\mu \mathrm{L}$ aliquot of pooled fractions 15-18 from the Bio-Gel P-2 column. Lanes $2,5-\mu \mathrm{L}$ aliquot of pooled fractions $25-27$ from the Sephacryl S-200 column.

were removed and the pellets were washed three times in washing buffer. The supernatants, washes, and pellets were then counted to determine the percentage of ${ }^{125}$ I-labeled IGF-I receptor immunoprecipitated. 


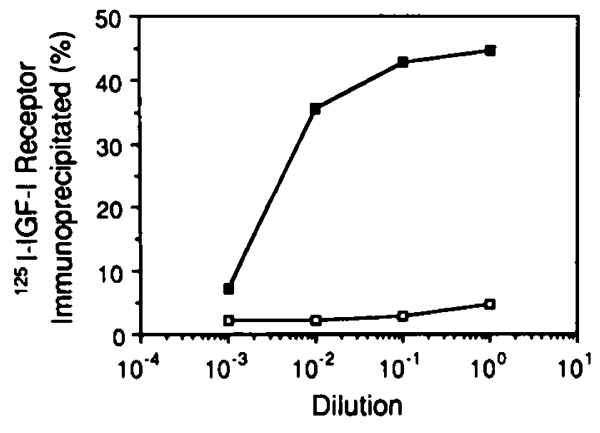

Fig. 2. Immunoprecipitation of IGF-I receptor by immune and nonimmune human serum. Forty-five $\mu \mathrm{L}(25075 \mathrm{cpm})$ of precleared ${ }^{125} \mathrm{I}$ labeled IGF-I receptor in washing buffer with $0.1 \%$ Triton X-100 and protease inhibitors were incubated overnight at $4^{\circ} \mathrm{C}$ with $5 \mu \mathrm{L}$ of serum from a patient with severe insulin resistance $(\square)$ or with $5 \mu \mathrm{L}$ of nonimmune human serum $(\square)$ at the dilutions indicated. Immune complexes were precipitated by the addition of $75 \mu \mathrm{L}$ of $20 \%$ Pansorbin in washing buffer, as described in Materials and Methods. Results are expressed as cpm immunoprecipitated/total $\mathrm{cpm}$ recovered $\times 100 \%$.

A
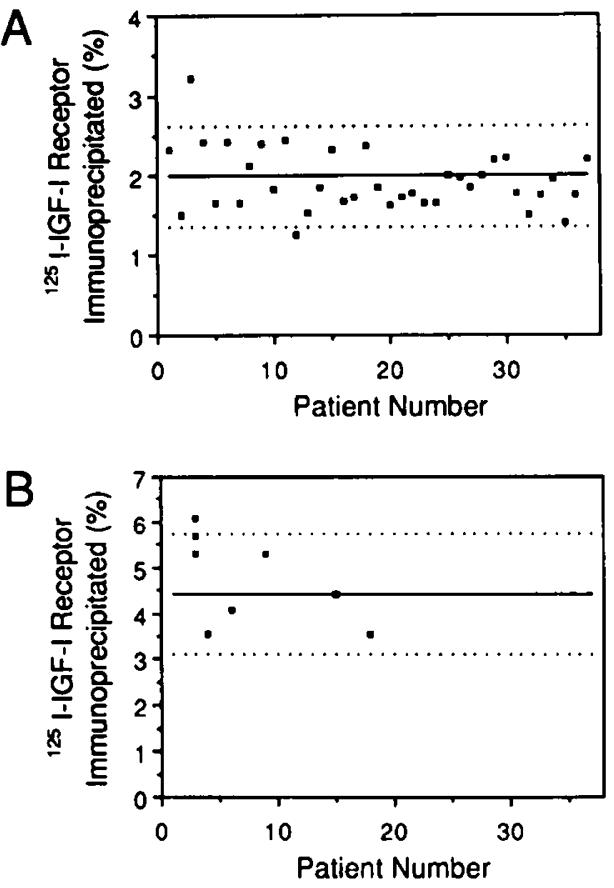

Fig. 3. Immunoprecipitation of IGF-I receptor by serum or plasma from short-statured children. Immunoprecipitation of the ${ }^{125}$ I-labeled IGF-I receptor was performed as described in Materials and Methods. Results are expressed as $\mathrm{cpm}$ immunoprecipitated/total $\mathrm{cpm}$ recovered $\times 100 \%$. The solid and dotted lines indicate the percentage (mean \pm 3 SD) of ${ }^{125}$ I-labeled IGF-I receptor immunoprecipitated by 1:10 diluted or by undiluted nonimmune human serum. $A$, immunoprecipitation of the ${ }^{125}$ I-labeled IGF-I receptor by a 1:10 dilution of patient serum or plasma. Data are plotted as the mean percentage of ${ }^{125}$ I-labeled IGF-I receptor immunoprecipitated by three samples obtained at different times from each patient, except for patient no. 29, from whom only two samples were obtained. $B$, immunoprecipitation of the ${ }^{125}$ I-labeled IGFI receptor by selected undiluted patient serum or plasma. Patient samples in which ${ }^{125}$ I-labeled IGF-I receptor immunoprecipitation was $>3 \mathrm{SD}$ above the mean when assayed at a 1:10 dilution were tested undiluted. Data are plotted as the mean percentage of ${ }^{125}$ I-labeled IGF-I receptor immunoprecipitated by each sample in one to three assays.
Immunoprecipitation of the precleared IGF-I receptor by $\alpha$ IR3 was performed as previously described (13), except that washing buffer with $0.1 \%$ Triton $\mathrm{X}-100$ and protease inhibitors was used in the incubation.

\section{RESULTS}

Radioiodination of purified IGF-I receptor. Previous experiments in our laboratory had suggested that radioiodination of the purified IGF-I receptor under some conditions caused reduction of intersubunit disulfide bonds. The solid phase radioiodination method, however, resulted in the generation of ${ }^{125} \mathrm{I}$-labeled IGF-I receptor that remained intact for use in immunoprecipitation studies. Figure 1 shows the column chromatography profiles and SDS-PAGE analysis of labeled IGF-I receptor after radioiodination using the Enzymobead Radioiodination Reagent. The ${ }^{125}$ I-labeled IGF-I receptor elutes in the void volume of the Bio-Gel P-2 column and is effectively separated from free ${ }^{125}$ I ( panel $A$ ). Human serum albumin is the major contaminant in our purified receptor preparations (10) and is effectively removed by gel filtration on the Sephacryl S-200 column (panel $B)$. SDS-PAGE and autoradiography were performed to demonstrate that the labeled IGF-I receptor was intact after radioiodination and to verify its purity (panel $C$ ). Under nonreducing conditions (left lanes), a single broad band with an apparent $M_{r}$ $>300000$ is resolved, indicating that the IGF-I receptor remains in its heterotetrameric form after radioiodination. Under reducing conditions (right lanes), the $\alpha$ - and $\beta$-subunits of the IGF-I receptor with apparent $M_{r}=131600$ and 100400 , respectively, and a less prominent band with an apparent $M_{r}=44000$, which represents the $\beta^{\prime}$-subunit (13), are resolved. Densitometric scans of the autoradiographs of ${ }^{125}$ I-labeled IGF-I receptor after Sephacryl S-200 column chromatography (lanes 2) demonstrated that the amount of label associated with the IGF-I receptor under nonreducing and reducing conditions was $74.8 \%$ and $73.7 \%$, respectively.

Immunoprecipitation of IGF-I receptor. Serum from a patient with severe insulin resistance significantly blocked IGF-I binding to renal basolateral membranes (personal communication, Gavin III JR) and was used as a positive control in our studies. Maximal immunoprecipitation of the ${ }^{125}$ I-labeled IGF-I receptor by this serum was achieved at a 1:10 dilution, as demonstrated in Figure 2. In five experiments, maximal immunoprecipitation of the IGF-I receptor by undiluted immune serum ranged from 28.9 to $44.7 \%$. Precipitation of the IGF-I receptor by undiluted nonimmune human serum ranged from 3.86 to $4.82 \%$. Immunoprecipitation of the IGF-I receptor was also performed using $\alpha \mathrm{IR}-3$, a mouse MAb specific to the human IGF-I receptor (14). Maximal immunoprecipitation of the ${ }^{125}$ I-labeled IGF-I receptor by this antibody ( $5 \mu \mathrm{L}$ undiluted) was $55 \%$. The comparable maximal immunoprecipitation achieved with serum from a patient with severe insulin resistance and with $\alpha$ IR-3 indicates that the immune serum contains antibodies that cross-react with the ${ }^{125} \mathrm{I}$ labeled IGF-I receptor.

Immunoprecipitation of IGF-I receptor by serum or plasma from children with short stature. Serum and plasma from 37 prepubertal children between the ages of 4.2 and $13.8 \mathrm{y}$ and $>2$ SD below the mean height for age were tested for their ability to immunoprecipitate purified ${ }^{125}$ I-labeled IGF-I receptor. Samples had been collected before the treatment protocol described previously (8). Figure $3 A$ shows the mean percentage of ${ }^{125} \mathrm{I}$-labeled IGF-I receptor immunoprecipitated by $1: 10$ dilutions of serum or plasma samples from each patient. Three samples obtained at different times from each patient were examined, except for patient no. 29 , from whom only two samples were obtained. The range of ${ }^{125}$ I-labeled IGF-I receptor immunoprecipitated by a $1: 10$ dilution of nonimmune human serum was $1.99 \pm 0.63 \%$ (mean $\pm 3 \mathrm{SD}, n=6$ ), as indicated by the solid and dotted lines. Three samples from patient no. 3 immunoprecipitated $3.12 \%$, $2.71 \%$, and $3.82 \%$ of the ${ }^{125}$ I-labeled IGF-I receptor. In addition, 
immunoprecipitation of ${ }^{125}$ I-labeled IGF-I receptor by a single sample from patients no. $4,6,9,15$, and 18 was $>3$ SD above the mean. Five of these six patients had normal levels of serum IGF-I. These samples were further tested undiluted, as shown in Figure $3 B$. The range of ${ }^{125}$ I-labeled IGF-I receptor immunoprecipitated by undiluted nonimmune human serum was $4.42 \pm$ $1.32 \%$ (mean $\pm 3 \mathrm{SD}, n=3$ ), again as indicated by the solid and dotted lines. Immunoprecipitation of ${ }^{125} \mathrm{I}$-labeled IGF-I receptor by seven of the eight samples from six patients was within 3 SD of the mean. One of three samples from patient no. 3 immunoprecipitated slightly more ${ }^{125}$ I-labeled IGF-I receptor than nonimmune human serum. We conclude from these data that among this patient group of short-statured children no significant circulating immunoprecipitating antibodies to the IGF-I receptor are present.

\section{DISCUSSION}

IGF-I resistance has been described in only a few children with growth failure. Bierich et al. (15) reported that fibroblasts from a short child with growth failure bound $50 \%$ less ${ }^{125}$ I-labeled IGF-I than normal fibroblasts, although the structure and function of the IGF-I receptor in this child's fibroblasts were not directly examined. Heath-Monnig et al. (16) reported that fibroblasts from a child with short stature were significantly less responsive to stimulation by IGF-I in $\alpha$-aminoisobutyric acid uptake assays. We have found that the resistance to IGF-I action in this patient's fibroblasts is caused by an abnormal production and/or cell association of IGF binding proteins (17). Potential mechanisms of IGF-I resistance include not only abnormalities in IGF-I receptor structure/function and abnormalities in the modulation of IGF-I action by IGF binding proteins but also inhibition of IGF-I action by circulating autoantibodies to IGFI, to the IGF-I receptor, or to one or more IGF binding proteins.

Autoantibodies to the homologous insulin receptor are not widespread. Insulin receptor antibodies were first identified in the plasma of patients with severe insulin resistance type B associated with acanthosis nigricans (6). Although some antibodies from these patients inhibit insulin binding, other antibodies mimic insulin action in vitro and in vivo. Recently, insulin receptor autoantibodies have also been reported in several patients who developed severe fasting hypoglycemia without a previous history of insulin resistance (18). The balance between agonistic and antagonistic antibodies, the titer of antibodies, and/ or the chronicity of exposure may be important determinants in the clinical response to insulin receptor antoantibodies (18). Although insulin receptor autoantibodies account for only a small number of patients with diabetes and/or hypoglycemia in the general population, studies of these antibodies have provided important insights into insulin action.

We undertook the present study to define the prevalence of autoantibodies to the IGF-I receptor in growing children. Kasuga et al. (19) reported that sera from five of seven patients with severe insulin resistance and acanthosis nigricans immunoprecipitated both placental insulin and IGF-I receptors. Autoantibodies to the IGF-I receptor were also found in sera from 11 patients with a variety of disorders reported to have an increased prevalence of insulin receptor antibodies (7). In this study, two sera from patients with severe insulin resistance type B were found to immunoprecipitate the labeled IGF-I receptor and to inhibit IGF-I binding. Maximal immunoprecipitation of ${ }^{125}$ I-labeled IGF-I receptor by these sera using a second antibody procedure was $\sim 14 \%$ and $\sim 40 \%$, which is similar to the immunoprecipitation achieved with the immune serum used as a positive control in our study. Immunoprecipitation of ${ }^{12 s}$ I-labeled IGF-I receptor by sera from eight of the remaining nine patients was only slightly greater than 3 SD above the mean when compared to immunoprecipitation by sera from control subjects. This study did not report any clinical effects related to IGF-I receptor antibodies in two patients (one of 31 with rheumatic disorders and one of seven with polycystic ovary syndrome) with modestly elevated IGF-I levels and did not include growing children, in whom inhibition of IGF-I action by IGF-I receptor autoantibodies would be anticipated to have significant clinical effects. We therefore examined serum and plasma samples from a wellcharacterized group of children with short stature. Because of potential interference by IGF binding proteins in screening sera with an assay to detect antibodies that block IGF-I binding, an immunoprecipitation assay method was used. It is unlikely that serum antibodies that block IGF-I binding but do not immunoprecipitate well would be missed in our assay, however, because Pansorbin (fixed protein A-bearing $S$. aureus cells) rather than a second antibody procedure was used. The equivalence titrations required for optimal precipitation of antigen-antibody complexes in the second antibody procedure can be dispensed with merely by providing protein $A$ sites in excess of the antiserum IgG sites, as we have done, resulting in superior recovery (20). A single serum sample from patient no. 3 immunoprecipitated slightly more ${ }^{125}$ I-labeled IGF-I receptor than nonimmune human serum, but immunoprecipitation of ${ }^{125}$ I-labeled IGF-I receptor by the other two of three samples from this patient was within 3 SD of the mean. This result therefore was probably not significant and was not investigated further. Although a small number of children were studied, our report documents for the first time that immunoprecipitating autoantibodies to the IGF-I receptor are not commonly present in short-statured children.

\section{REFERENCES}

1. Daughaday WH, Rotwein P 1989 Insulin-like growth factors I and II. Peptide. messenger ribonucleic acid and gene structures, serum, and tissue concentrations. Endocr Rev 10:68-91

2. Yarden Y, Ullrich A 1988 Growth factor receptor tyrosine kinases. Annu Rev Biochem 57:443-478

3. Ullrich A, Gray A, Tam AW, Yang-Feng T, Tsubokawa M, Collins C, Henzel W, LeBon T, Kathuria S, Chen E, Jacobs S, Francke U, Ramachandran J, Fujita-Yamaguchi Y 1986 Insulin-like growth factor I receptor primary structure: comparison with insulin receptor suggests structural determinants that define functional specificity. EMBO J 5:2503-2512

4. Froesch ER, Schmid C. Schwander J, Zapf J 1985 Actions of insulin-like growth factors. Annu Rev Physiol 47:443-467

5. Wilkin TJ 1990 Receptor autoimmunity in endocrine disorders. N Engl J Med 323:1318-1324

6. Flier JS, Kahn CR, Roth J 1979 Receptors, antireceptor antibodies and mechanisms of insulin resistance. N Engl J Med 300:413-419

7. Tappy L. Fujita-Yamaguchi Y, LeBon TR, Boden G 1988 Antibodies to insulin-like growth factor $I$ receptors in diabetes and other disorders. Diabetes 37:1708-1714

8. Dempsher DP, Bier DM, Tollefsen SE, Rotwein PS, Daughaday WH, Jensen MC, Galgani JP, Heath-Monnig E, Trivedi B 1990 Whole body nitrogen kinetics and their relationship to growth in short children treated with recombinant human growth hormone. Pediatr Res 28:394-400

9. Goding JW 1978 Use of staphylococcal protein A as an immunological reagent. J Immunol Methods 20:241-253

10. Tollefsen SE, Thompson K, Petersen DJ 1987 Separation of the high affinity insulin-like growth factor I receptor from low affinity binding sites by affinity chromatography. J Biol Chem 262:16461-16469

11. Laemmli UK 1970 Cleavage of structural proteins during assembly of the head of bacteriophage T4. Nature 227:680-685

12. Tollefsen SE, Kornfeld R 1983 Isolation and characterization of lectins from Vicia villosa. Two distinct carbohydrate binding activities are present in seed extracts. J Biol Chem 258:5165-5171

13. Tollefsen SE, Thompson $\mathrm{K} 1988$ The structural basis for insulin-like growth factor I receptor high affinity binding. J Biol Chem 263:16267-16273

14. Kull FC, Jacobs S, Su Y-F, Svoboda M, Van Wyk JJ, Cuatrecasas P 1983 Monoclonal antibodies to receptors for insulin and somatomedin-C. J Biol Chem 258:6561-6566

15. Bierich JR, Moeller H, Ranke MB, Rosenfeld RG 1984 Pseudopituitary dwarfism due to resistance to somatomedin: a new syndrome. Eur J Pediatr 142:186-188

16. Heath-Monnig E, Wohltmann HJ, Mills-Dunlap B, Daughaday WH 1987 Measurement of insulin-like growth factor I (IGF-I) responsiveness of fibroblasts of children with short stature: identification of a patient with IGF-I resistance. J Clin Endocrinol Metab 64:501-507 
17. Tollefsen SE, Heath-Monnig E, Cascieri MA, Bayne ML, Daughaday WH 1991 Endogenous insulin-like growth factor (IGF) binding proteins cause IGF-I resistance in cultured fibroblasts from a patient with short stature. J Clin Invest 87:1241-1250

18. Taylor SI, Barbetti F, Accili D, Roth J, Gorden P 1989 Syndromes of auto immunity and hypoglycemia: autoantibodies directed against insulin and its receptor. Endocrinol Metab Clin North Am 18:123-143
19. Kasuga M, Sasaki N, Kahn CR, Nissley SP, Rechler MM 1983 Antireceptor antibodies as probes of insulin-like growth factor receptor structure. J Clin Invest 72:1459-1469

20. Kessler SW 1981 Use of protein-A bearing staphylococci for the immunoprecipitation and isolation of antigens from cells. Methods Enzymol 73:442459

\section{Announcement}

\section{Call for Abstracts}

The American Pediatric Society and The Society for Pediatric Research announce that the abstract deadline for the 1993 Annual Meeting (May 3-6, 1993, Sheraton Washington Hotel, Washington, DC) has been set as January 5, 1993. For further information contact: APS/SPR Association Headquarters, 141 Northwest Point Blvd., P.O. Box 675, Elk Grove Village, IL 60009-0675. 